\title{
Honey - a potential agent against Porphyromonas gingivalis: an in vitro study
}

Sigrun Eick ${ }^{1 *}$, Gesine Schäfer ${ }^{2}$, Jakub Kwieciński ${ }^{3}$, Julia Atrott ${ }^{4}$, Thomas Henle ${ }^{4}$ and Wolfgang Pfister ${ }^{2}$

\begin{abstract}
Background: Honey has been discussed as a therapeutic option in wound healing since ancient time. It might be also an alternative to the commonly used antimicrobials in periodontitis treatment. The in-vitro study was aimed to determine the antimicrobial efficacy against Porphyromonas gingivalis as a major periodontopathogen.

Methods: One Manuka and one domestic beekeeper honey have been selected for the study. As a screening, MICs of the honeys against $20 \mathrm{P}$. gingivalis strains were determined. Contents of methylglyoxal and hydrogen peroxide as the potential antimicrobial compounds were determined. These components (up to $100 \mathrm{mg} / \mathrm{l}$ ), propolis (up to $200 \mathrm{mg} / \mathrm{l}$ ) as well as the two honeys (up to $10 \% \mathrm{~W} / \mathrm{V}$ ) were tested against four $P$. gingivalis strains in planktonic growth and in a single-species biofilm.
\end{abstract}

Results: $2 \%$ of Manuka honey inhibited the growth of $50 \%$ of the planktonic $P$. gingivalis, the respective $\mathrm{MIC}_{50}$ of the German beekeeper honey was 5\%. Manuka honey contained $1.87 \mathrm{mg} / \mathrm{kg}$ hydrogen peroxide and the domestic honey $3.74 \mathrm{mg} / \mathrm{kg}$. The amount of methylglyoxal was found to be $2 \mathrm{mg} / \mathrm{kg}$ in the domestic honey and $982 \mathrm{mg} / \mathrm{kg}$ in the Manuka honey. MICs for hydrogen peroxide were $10 \mathrm{mg} / \mathrm{l}-100 \mathrm{mg} / \mathrm{l}$, for methylglyoxal 5 - $20 \mathrm{mg} / \mathrm{l}$, and for propolis $20 \mathrm{mg} / \mathrm{l}-200 \mathrm{mg} / \mathrm{l}$. 10\% of both types of honey inhibited the formation of $P$. gingivalis biofilms and reduced the numbers of viable bacteria within $42 \mathrm{~h}$-old biofilms. Neither a total prevention of biofilm formation nor a complete eradication of a $42 \mathrm{~h}$-old biofilm by any of the tested compounds and the honeys were found.

Conclusions: Honey acts antibacterial against $P$. gingivalis. The observed pronounced effects of Manuka honey against planktonic bacteria but not within biofilm can be attributed to methylglyoxal as the characteristic antimicrobial component.

Keywords: Honey, Porphyromonas gingivalis, Biofilm, Methylglyoxal, Minimal inhibitory concentration

\section{Background}

Periodontitis is a chronic inflammation that occurs in response to the presence of subgingival bacteria. A limited number of bacterial species have been associated with periodontitis, and strong evidence has been accumulated to implicate Porphyromonas gingivalis, an anaerobic gram-negative bacterium in the pathogenesis [1-3]. Moreover $P$. gingivalis was postulated to be a keystone pathogen in developing periodontal disease [4], virulence is most associated with its high proteolytic activity [5].

Based on the impact of pathogens, the antiinfective regimen is an important component in any treatment of periodontitis. In preventing recolonization of bacteria,

\footnotetext{
* Correspondence: sigrun.eick@zmk.unibe.ch

'Department of Periodontology, Laboratory of Oral Microbiology, Dental School, University of Bern, Freiburgstrasse 7, CH-3010 Bern, Switzerland Full list of author information is available at the end of the article
}

chlorhexidine digluconate (CHX) is a widely used agent in periodontitis treatment [6,7]. Antibiotics are recommended for severe cases $[8,9]$. Development of resistance against antibiotics and side effects of the drugs implicate search for alternatives. Among others, plant-based therapy including the combination with antibiotics or the usage of honey might be one option $[10,11]$.

Honey is an ancient wound treatment and was reintroduced into modern medical therapy because of its antimicrobial and wound-healing promoting efficacy [12]. Hydrogen peroxide was found to be an antibacterial constituent of honey [13]. For a couple of years special interest has been focused on the Manuka honey that derives from the Manuka tree (Leptospermum scoparium) growing in New Zealand. In the Manuka honey, having a high non peroxide activity, methylglyoxal was identified 
as the dominant antibacterial constituent [14]. Honey has been proven to be effective in treatment of recurrent herpes simplex lesions [15], burn wounds [16], postoperative infected wounds [17]. It was found to reduce numbers of mutans streptococci in saliva of xerostomic patients [18]. In patients with gingivitis and plaque, the Manuka honey was able to reduce bleeding and the amount of plaque [19].

Another important bee product having an antimicrobial activity is propolis, a resinous substance which bees use for sealing of their combs [20]. As an additive to toothpastes [21] or irrigation [22], propolis may promote periodontal health.

Our study was aimed to determine the effect of two types of honey and of their most known antimicrobial compounds hydrogen peroxide and methylglyoxal, as well as of propolis on $P$. gingivalis strains in planktonic growth and in a single-species biofilm.

\section{Methods}

\section{Porphyromonas gingivalis strains}

Twenty $P$. gingivalis strains from the strain collection of the Laboratory of Oral Microbiology (University of Bern, Department of Periodontology) were included in the screening experiments determining minimal inhibitory concentration (MIC) values of the honeys. Strains included were two laboratory strains (ATCC 33277, W83) and 18 banked as isolates from periodontitis samples (BGH402, D2-4-3, D5-2-2, J358-1, J361-1, J362-1, J374-1, J378-1, J424-1, J426-1, J430-1, J435-1, J439-1, M5-1-2, MaRL, PL55, PL110, PL126). In the follow-up experiments the type strain ATCC 33277 and three other strains (M5-1-2, MaRL, J361-1) were used. The selection was based on the different colony morphology. M5-1-2 strain forms smooth colonies, MaRL very rough ones and J361 colonies similar to those formed by the type strain. The identity was confirmed by $16 \mathrm{~S} \mathrm{rDNA}$ sequence analysis.

All strains were kept frozen prior to the experiments. They were transferred and cultured anaerobically $\left(10 \% \mathrm{H}_{2}\right.$, $5 \% \mathrm{CO}_{2}, 85 \% \mathrm{~N}_{2}$ ) on Schaedler agar plates (Oxoid, Basingstoke, GB) containing $8 \%$ sheep blood $24 \mathrm{~h}$ before starting the experiments at $37^{\circ} \mathrm{C}$.

\section{Honeys, their potentially antimicrobial compounds and propolis}

A local (German) multifloral blossoms honey from a beekeeper and a New Zeeland Manuka honey (Manuka Health New Zeeland Ltd, Te Awamutu, New Zeeland) were selected for the experiments. Tests of culturing the two honeys in anaerobic conditions did not show any microbial growth; therefore no gamma irradiation was applied. All media in the experiments with honey contained $0.1 \%(\mathrm{v} / \mathrm{v})$ Tween 20 to increase solubility of honey.

The content of hydrogen peroxide was measured by means of potassium permanganate [23] and those of methylglyoxal was determined by reverse-phase, highperformance liquid chromatography (RP-HLPC) according to Mavric et al. [14]. Methylglyoxal and hydrogen peroxide (both Sigma-Aldrich, Steinheim, Germany) were available as $40 \%$ and $30 \%$ solution in water. The propolis was obtained as a $20 \%$ ethanolic dilution from a local beekeeper. Thus, in all experiments testing propolis, the respective amount of ethanol was added.

\section{Determination of minimal inhibitory concentrations}

The susceptibilities were determined by the micro-bouillon dilution technique being a standard technique in microbiology [24]. 17 parts (170 $\mu$ l each) of Wilkins-Chalgren broth (Oxoid) were mixed with 1 part of bacterial suspension $(10 \mu \mathrm{l})$ and 2 parts of the honey diluted in $0.9 \%$ sodium chloride $(20 \mu \mathrm{l}$ each). The final concentrations ranged between 1 and 10\% (w/v) honey. Similarly, the MICs of methylglyoxal and hydrogen peroxide were determined. The concentrations to be tested were between 0.1 and $100 \mathrm{mg} / \mathrm{l}$. The propolis was tested in the range of $20-$ $20,000 \mathrm{mg} / \mathrm{l}$. $0.9 \%$ sodium chloride solution served as growth control. After an incubation time of $42 \mathrm{~h}$, the MICs were determined visually. The results were confirmed by subculturing of each $10 \mu \mathrm{l}$ of broth on Schaedler agar plates. The MIC was defined as the lowest concentration repressing visible growth.

\section{Single-species biofilms}

The bacterial strains were precultured in Schaedler broth (Oxoid) added by $8 \%$ lysed sheep blood overnight. To determine effects on a forming biofilm assay, slides were placed into wells of 24-well plates and have been covered with artificial saliva $\left(250 \mu \mathrm{l}\right.$ each) for $1 \mathrm{~h}$ at $37^{\circ} \mathrm{C}$ to create a pellicle. $1 \mathrm{l}$ of the saliva (ISO 10993) contained $0.7 \mathrm{~g}$ sodium chloride, $0.26 \mathrm{~g}$ disodium phosphate, $0.33 \mathrm{~g}$ potassium thiocyanate, $1.2 \mathrm{~g}$ potassium dihydrogen phosphate $1.5 \mathrm{~g}$ sodium hydrogen carbonate and $1.2 \mathrm{~g}$ potassium chloride; this solution was supplemented with $4 \mathrm{~g}$ porcine mucin type II and $50 \mathrm{~g}$ albumine. After removal of the artificial saliva, $1.8 \mathrm{ml}$ of bacterial suspension was transferred to the wells, followed by $200 \mu \mathrm{l}$ of honey in different dilutions. The final concentrations of honey in the mixtures were 1 and $10 \%(\mathrm{w} / \mathrm{v})$. The negative control was $0.9 \%$ sodium chloride solution. After $6 \mathrm{~h}$ and $24 \mathrm{~h}$ of incubation in an anaerobic atmosphere at $37^{\circ} \mathrm{C}$, the slides were removed, shortly dipped into $0.9 \%$ sodium chloride solution to remove non adherent bacteria and then placed into other tubes containing $0.9 \%$ sodium chloride solution. The tubes have been exposed to ultrasonication of $160 \mathrm{~W}$ (Sonorex Super RK102H, Bandelin, Berlin, Germany) for $1 \mathrm{~min}$. After a subsequent vortexing for $1 \mathrm{~min}$, the numbers of viable $P$. gingivalis were determined as colony forming units (CFU) after plating of $100 \mu \mathrm{l}$ of the suspension on Schaedler agar plates and cultivation. 
Further, the effects of the honeys on a $42 \mathrm{~h}$-old biofilm were tested. In these experiments, the bacterial suspensions were placed into the wells after creating the artificial pellicle. Forty-two hours after starting incubation, the supernatants were carefully removed and replaced by nutrient broth and honey solutions. The final concentrations used in these experiments were also $1 \%$ and $10 \%(\mathrm{w} / \mathrm{v})$ honey. After an additional incubation time of $6 \mathrm{~h}$ and $24 \mathrm{~h}$, the numbers of viable bacteria were determined as described above.

In follow-up experiments, hydrogen peroxide and methylglyoxal were tested instead of honey. The final concentrations were 5, 20 and $100 \mathrm{mg} / \mathrm{l}$ hydrogen peroxide and methylglyoxal respectively. The propolis was tested in the final concentrations of $20 \mathrm{mg} / \mathrm{l}$ and $200 \mathrm{mg} / \mathrm{l}$.

All experiments were made in three independent repetitions at least. The statistical analysis was made by Student's t-test for independent samples by using SPSS Statistics v.17.0 (IBM, Chicago, IL). Test samples were each compared with controls. The level of significance was set to $\mathrm{p}<0.05$.

\section{Results}

\section{Content of potentially antimicrobial compounds}

The Manuka honey contained $1.87 \mathrm{mg} / \mathrm{kg}$ hydrogen peroxide and the domestic honey $3.74 \mathrm{mg} / \mathrm{kg}$. The amount of methylglyoxal was found to be $2 \mathrm{mg} / \mathrm{kg}$ in the domestic honey and $982 \mathrm{mg} / \mathrm{kg}$ in the Manuka honey.

\section{Minimal inhibitory concentrations}

In the screening assays including $20 P$. gingivalis strains, the minimal inhibitory concentration against $50 \%$ of the included strains $\left(\mathrm{MIC}_{50}\right)$ was $5 \%$ for the local domestic beekeeper honey and $2 \%$ for the Manuka honey. The domestic honey did not inhibit the growth of three strains up to $10 \%$ of the honey, whereas the growth of only one strain was not suppressed by $10 \%(\mathrm{w} / \mathrm{v})$ Manuka honey.

In continuing experiments four strains were included. The growth of $P$. gingivalis strains was inhibited by $10 \mathrm{mg} / \mathrm{l}$ of methylglyoxal with the exception of the reference strain (ATCC 33277) where the MIC was $100 \mathrm{mg} / \mathrm{l}$ of the compound. The range of the MICs of hydrogen peroxide was between 5 and $20 \mathrm{mg} / \mathrm{l}$. The propolis was growth-inhibitory in the range of $20 \mathrm{mg} / \mathrm{l}$ (M5-1-2 strain) to $200 \mathrm{mg} / \mathrm{l}$ (MaRL strain) (Table 1).

\section{Effects of honey on biofilms}

Honey inhibited the formation of $P$. gingivalis singlespecies biofilm. Six hours after starting experiments, no differences were visible. At the $24 \mathrm{~h}$ time, both kinds of honey reduced concentration-dependently the numbers of viable bacteria. When the higher concentration of $10 \%$ was used, the numbers of bacteria in biofilm (mean of all strains) were significantly lower (each $p<0.05)$ than in the controls without addition of honey (Figure 1).

Addition of the honeys to an $42 \mathrm{~h}$-old biofilm resulted also in a reduction of the mean counts of $P$. gingivalis strains within the biofilm $6 \mathrm{~h}$ and $24 \mathrm{~h}$ after exposure $(6 \mathrm{~h}$ $1 \%$ locally produced honey $\mathrm{p}<0.05$, all others $\mathrm{p}<0.01$ ). The differences between the two types of honey were never significant within the same concentration neither in the experiments testing the effect on biofilm formation nor if a $42 \mathrm{~h}$-old biofilm was studied (Figure 1).

When analyzing the strain dependent effects, the clinical isolates were more susceptible in comparison with the type strain (control). The differences were significant $(\mathrm{p}<0.05)$ for $1 \%(\mathrm{w} / \mathrm{v})$ of Manuka honey $6 \mathrm{~h}$ after starting biofilm formation. In the experiments testing the effects of honeys on $42 \mathrm{~h}$-old biofilms, $10 \%$ of the Manuka honey $(\mathrm{p}<0.05)$ as well as $1 \%$ and $10 \%$ of the locally produced honey (each $\mathrm{p}<0.01$ ) showed a stronger antibacterial efficacy on clinical isolates than on the reference strain $6 \mathrm{~h}$ after addition to the existing biofilms. $24 \mathrm{~h}$ after addition of the honeys to both types of the experiments, strain dependent differences were not visible any longer (Figure 2).

\section{Effects of methylglyoxal and hydrogen peroxide on biofilms}

The addition of the antibacterial compounds methylglyoxal and hydrogen peroxide did not change the CFU counts of $P$. gingivalis within biofilm at any time point, neither in the biofilm-forming assays nor in the experiments using $42 \mathrm{~h}$-old biofilms (Figure 3). Further, strain dependent differences were not detected (data not shown).

\section{Effect of propolis on biofilms}

A propolis concentration of $20 \mathrm{mg} / \mathrm{l}$ reduced the CFU counts in the forming biofilm after $24 \mathrm{~h}(\mathrm{p}<0.05)$. No effects were found by testing the higher concentration of $200 \mathrm{mg} / \mathrm{l}$. Addition of the propolis to a $42 \mathrm{~h}$-old biofilm did not change the numbers of bacteria after $6 \mathrm{~h}$. After $24 \mathrm{~h}$ the lower concentration of $20 \mathrm{mg} / \mathrm{l}$ propolis was effective in reducing the CFU counts; again, $200 \mathrm{mg} / \mathrm{l}$ did not show any effect (Figure 4). The most resistant strain was the MaRL strain; in the forming biofilm as well in the 42 h-old biofilm, higher CFU counts were found in comparison to the other strains after $24 \mathrm{~h}$ addition of $200 \mathrm{mg} / \mathrm{l}$ propolis (data not shown).

\section{Discussion}

Honey acts antibacterial against $P$. gingivalis strains, the effect is being more pronounced for the Manuka honey compared to a locally produced beekeeper honey. The obtained MIC values are in the range or below those reported for other species. E.g., $10-50 \%$ honey were growth inhibitory against several enterobacteriacae and staphylococci, different kinds of honey showed only low 
Table 1 Minimal inhibitory concentrations (MIC) of honeys, their potential antimicrobial components and propolis against four Porphyromonas gingivalis strains

\begin{tabular}{|c|c|c|c|c|c|}
\hline \multirow{2}{*}{$\begin{array}{l}\text { Porphyromonas } \\
\text { gingivalis strain }\end{array}$} & \multicolumn{2}{|c|}{ MIC of honeys $(\% \mathrm{w} / \mathrm{v})$} & \multirow{2}{*}{\multicolumn{2}{|c|}{$\begin{array}{l}\text { MIC of components (mg/l) } \\
\text { Hydrogen peroxide methylglyoxa }\end{array}$}} & \multirow{2}{*}{$\begin{array}{c}\text { MIC of } \\
\text { propolis (mg/l) }\end{array}$} \\
\hline & Manuka & Local & & & \\
\hline ATCC 33277 & 2 & 5 & 10 & 100 & 40 \\
\hline M5-1-2 & 2 & 5 & 5 & 10 & 20 \\
\hline MaRL & 2 & 10 & 20 & 10 & 200 \\
\hline J361-1 & 2 & 5 & 5 & 10 & 40 \\
\hline
\end{tabular}

differences in antimicrobial efficacy [25-27]. Contradictory are the results concerning oral microbes. In one study MICs of 12.5 - 25\% were determined against oral streptococci [25], whereas others found $0.1 \%$ growth-inhibitory against oral streptococci and anaerobes [28].
Honey contains different antimicrobial compounds. In this study, hydrogen peroxide and methylglyoxal were separately tested. The content of methylglyoxal within Manuka honey was nearly $1 \mathrm{~g} / \mathrm{kg}$, slightly higher than determined by others $[29,30]$. Following from the MICs
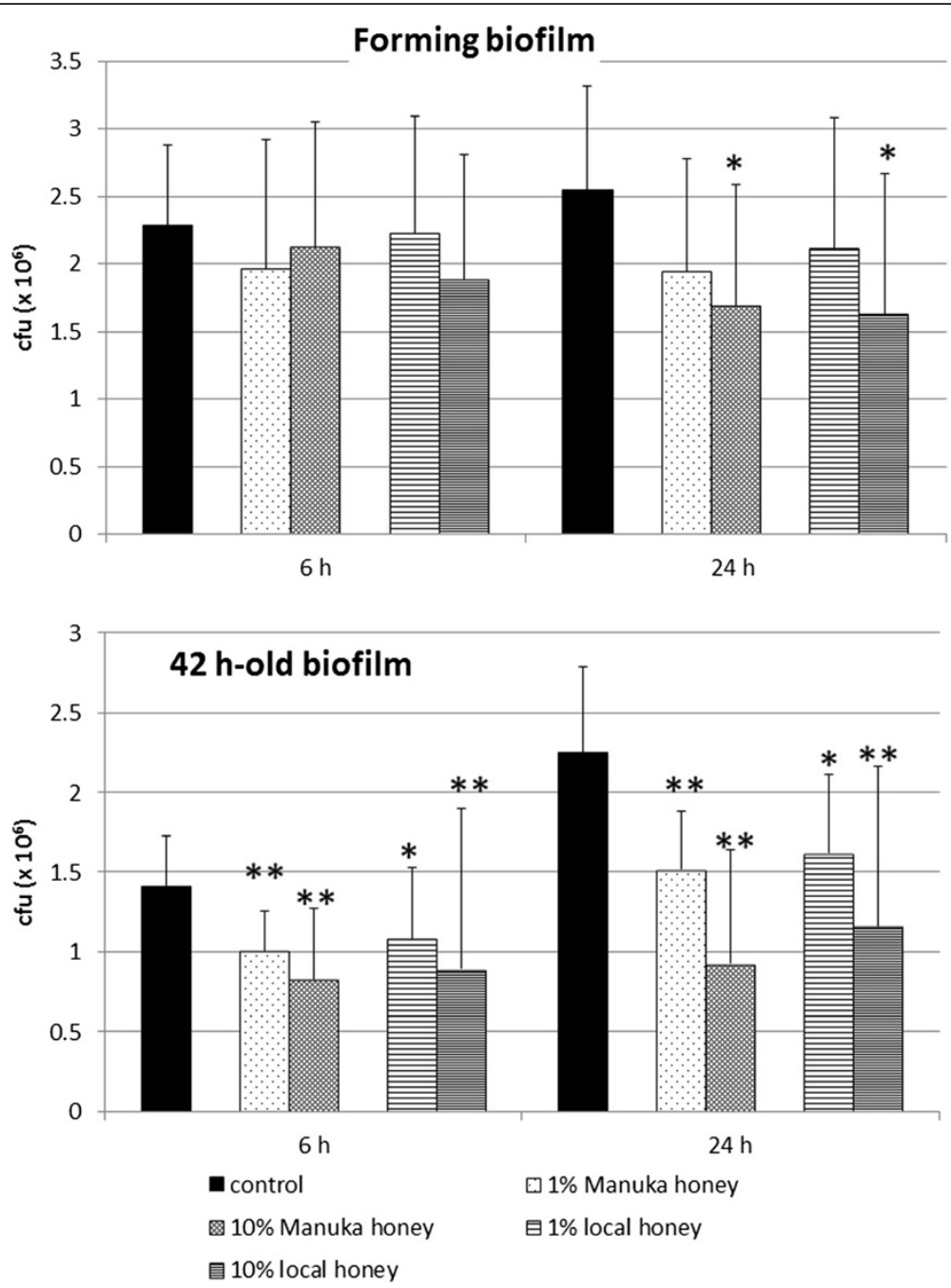

Figure 1 Effect of honey on formation as well as on a $\mathbf{4 2} \mathrm{h}$-old single biofilms of four Porphyromonas gingivalis strains. Manuka honey and a German local honey were added in two concentrations at the beginning of formation or on an already 42-h old biofilm. Colony forming units were determined each $6 \mathrm{~h}$ and $24 \mathrm{~h}$ after addition of the honeys (CFU counts within biofilm; ${ }^{*} \mathrm{p}<0.05 ;{ }^{* *} \mathrm{p}<0.01$ compared to controls at the respective time). 

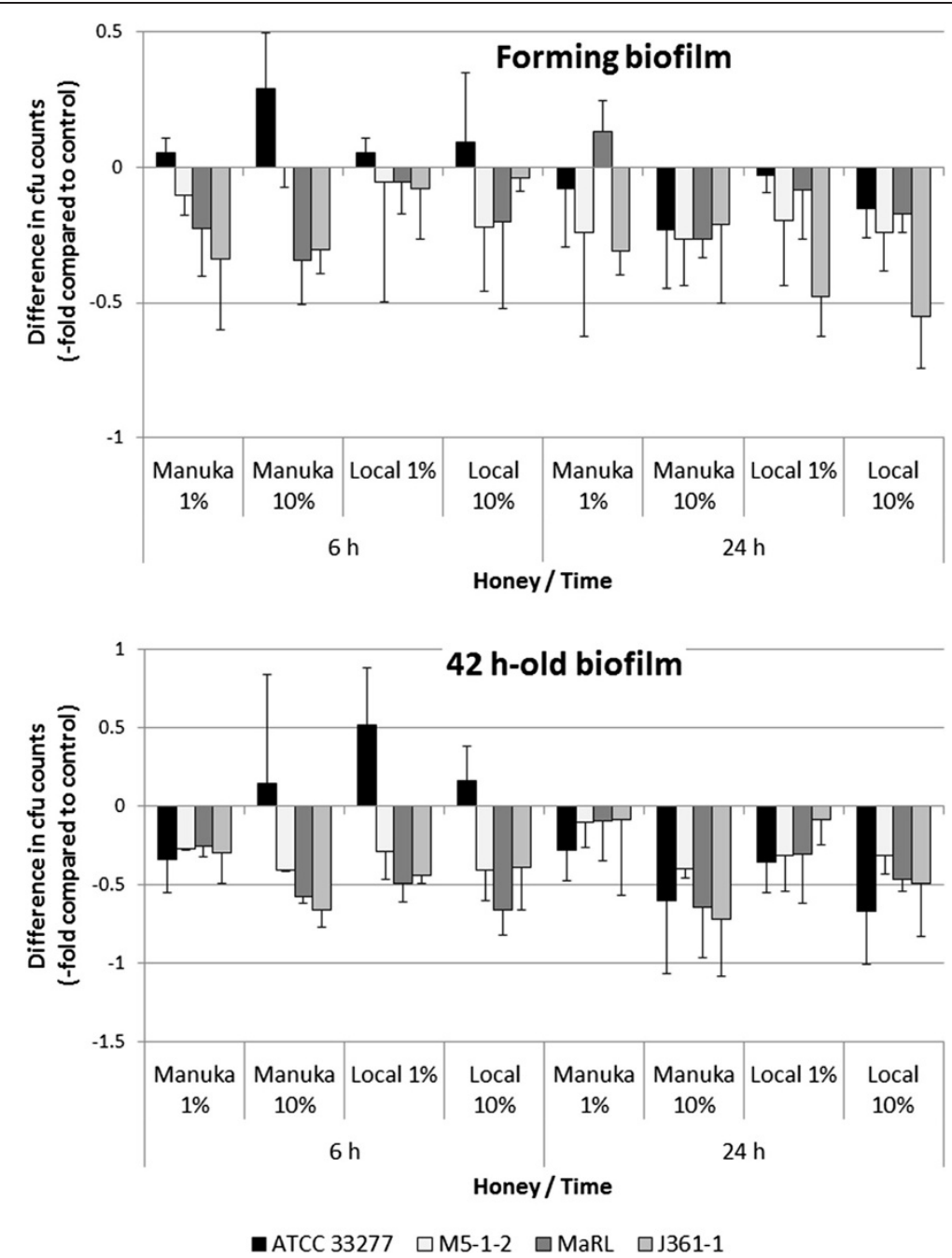

Figure 2 Relations of single Porphyromonas gingivalis biofilms after addition of honeys to untreated controls each (colony forming units).

of the honeys and methylglyoxal, this compound might be responsible for the antimicrobial activity of the Manuka honey against the planktonic $P$. gingivalis strains. The hydrogen peroxide content was higher in the domestic honey than in the Manuka honey. Others did not find any hydrogen peroxide within Manuka honey [30]. But another study where antimicrobial efficacy was decreased when hydrogen peroxide was removed from Manuka honey implicates also a content of that substance within honey. Our results obtained by a widely used method might be false positively influenced by organic compounds of the honey [23]. Nevertheless, the measured concentrations of hydrogen peroxide within both types of honey were much too low for an antimicrobial action against the $P$. gingivalis strains included in our study. But interestingly, the strain exhibiting the most resistance against hydrogen peroxide was also least sensitive to the locally produced honey. Another not studied potential antimicrobial compound in the honey is the sugar but it exerts no or limited antibacterial affect $[25,26]$. Moreover, naturally occurring antimicrobial peptides might contribute to the antimicrobial efficacy of the honeys, recently a bee defensin has been discovered in a Medical (Revamil ${ }^{\circledR}$ source) honey [30]. Further, an effect of a decreasing $\mathrm{pH}$ cannot be completely excluded, as $10 \%$ of honey reduced the $\mathrm{pH}$ by about $\mathrm{pH} 0.3$ as measured in broth. Propolis acts antibacterial against different oral anaerobes among them $P$. gingivalis [31]; MICs of propolis against $P$. gingivalis ATCC 33277 were reported in two studies as being between 64 and $512 \mathrm{mg} / \mathrm{l}$ (different kinds of propolis originating from Brazil and Turkey have been tested) [32,33]. In our study, only one kind of propolis originating from a lowland region in Germany characterized by a temperate climate was included. MIC against P. gingivalis ATCC 33277 was found to be slightly lower than reported before. MICs against the clinical isolates were not unique; the range was $20-200 \mathrm{mg} / \mathrm{l}$. 

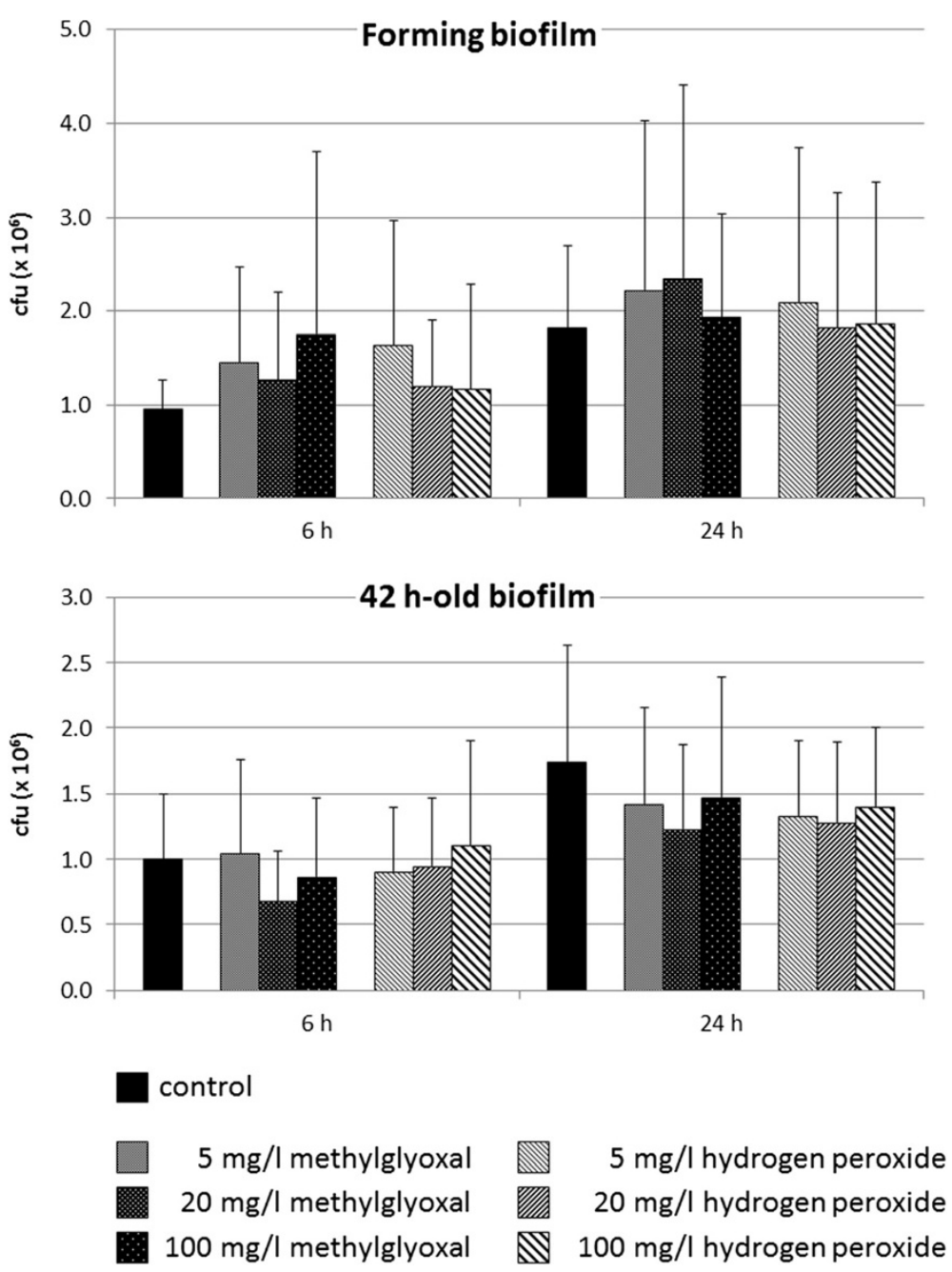

Figure 3 Effect of potential antimicrobial compounds of honey on formation as well as on a $\mathbf{4 2} \mathrm{h}$-old existing single-species biofilms of four Porphyromonas gingivalis strains. Methylglyoxal being the potential antimicrobial compound of Manuka honey and hydrogen peroxide as the potential antimicrobial compound of local German honey were added in three concentrations at the beginning of formation or on an already $42-\mathrm{h}$ old biofilm. Colony forming units were determined each $6 \mathrm{~h}$ and $24 \mathrm{~h}$ after addition of the compounds (CFU counts within biofilm; ${ }^{*} \mathrm{p}<0.05$; ${ }^{* *} \mathrm{p}<0.01$ each compared to controls at the respective time).

Biofilms are known to be more resistant against antimicrobials than planktonic growing bacteria; antibiotics are 100-fold less sensitive against $P$. gingivalis in biofilm [34]. Therefore, honeys including its potentially antimicrobial compounds were also tested on a $P$. gingivalis biofilm. The used model was a simple one using artificial saliva to simulate oral conditions. But it has to be noted that dental plaque represents a much more complex highly organized biofilm [35,36] consisting up to 7000 species-level phylotypa [37], where communication occurs within different species [38]. Here, we wanted to show a potential effect on a forming biofilm representing the in vivo situation after mechanical disruption of a biofilm and on a $42 \mathrm{~h}$-old biofilm. The efficacy of honey and its compounds on $P$. gingivalis biofilms was limited. Neither a complete eradication of a 42 h-old biofilm nor a total prevention of a biofilm formation was shown. Only $10 \%$ of both kinds of honey as well as $20 \mathrm{mg} / \mathrm{l}$ propolis were able to reduce the CFU counts within biofilm $24 \mathrm{~h}$ after beginning of biofilm formation. Surprisingly, the effects of honey were more remarkable on a $42 \mathrm{~h}$-old biofilm. In our study the action of especially the Manuka honey against $P$. gingivalis biofilms seems to be not only due to a bactericidal effect of methylglyoxal as is was itself non effective under those conditions. A potential interaction with $P$. gingivalis capsule may play a role in disrupting biofilms suggested by the finding that in contrast to most clinical isolates the most resistant ATCC 33277 strain is characterized by missing capsule formation $[39,40]$. Recently, it was reported that about $25-50 \%$ of honey were bactericidal to $S$. aureus including methicillin-resistant strains and Pseudomonas 

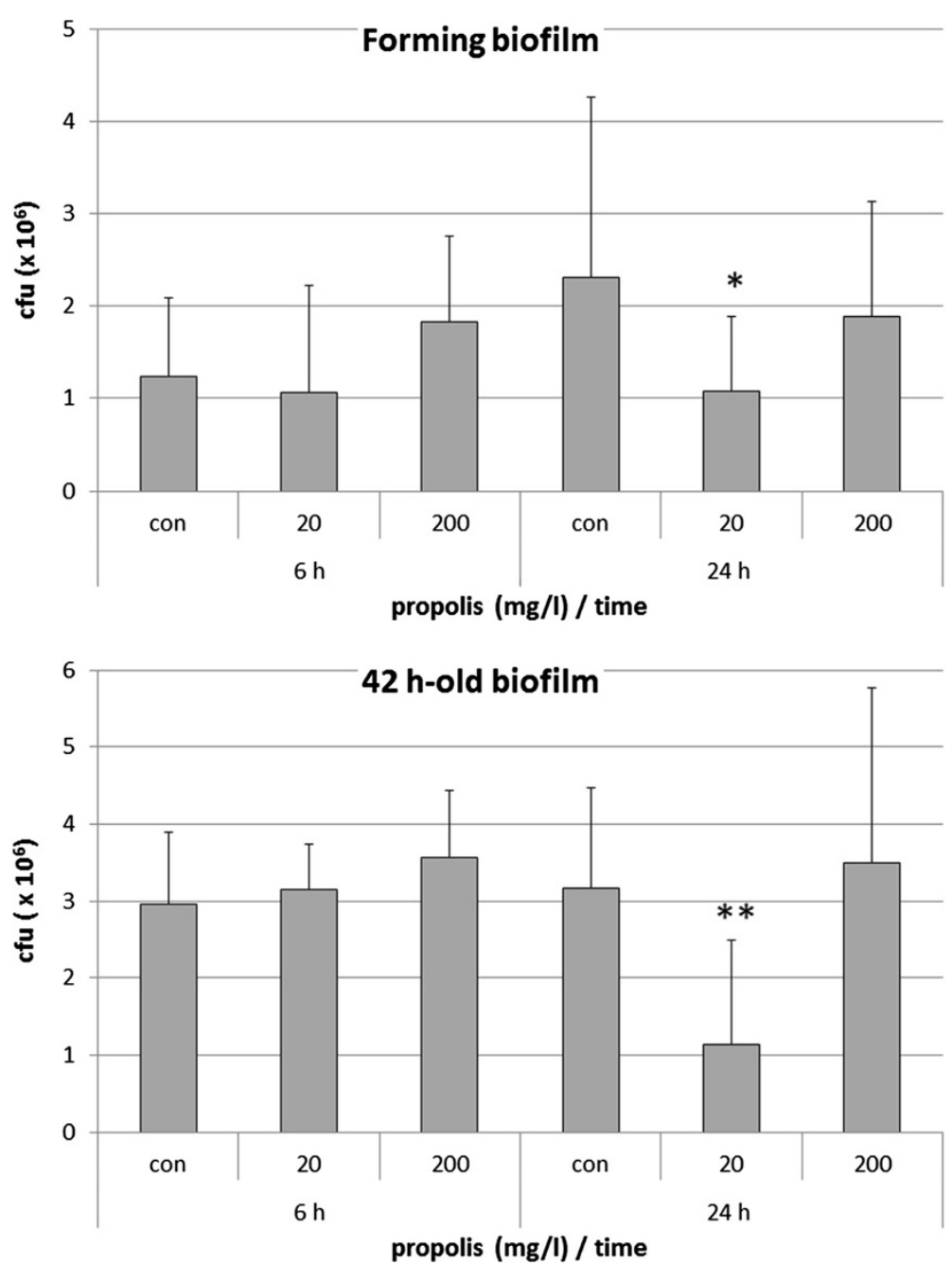

Figure 4 Effect of propolis on formation as well as on a $42 \mathrm{~h}$-old single-species biofilms of four Porphyromonas gingivalis strains. Propolis was added in two concentrations at the beginning of formation or on an already $42-\mathrm{h}$ old biofilm. Colony forming units were determined each $6 \mathrm{~h}$ and $24 \mathrm{~h}$ after addition of propolis (CFU counts within biofilm; ${ }^{*} \mathrm{p}<0.05$; ${ }^{* *} \mathrm{p}<0.01$ each compared to controls at the respective time).

aeruginosa overnight single-species biofilm, contrary to most of the antibiotics that did not show any effect [41]. Another study found $6-12 \%$ of Manuka honey and $12-25 \%$ of a Norwegian forest honey preventive in biofilm formation of staphylococci and gram-negative aerobes [42]. Only one study examined the effect of methylglyoxal on biofilm formation, $1.05 \mathrm{mg} / \mathrm{ml}$ methylglyoxal were bactericidal against 30 h-old $S$. aureus biofilms [29]. Interestingly, this value was also higher than those measured in its respective honey [29] implicating that methylglyoxal is not the only compound acting bactericidal. In these studies the tested concentrations of honey and methylglyoxal were higher than in ours assays. We had to ensure suitable growth conditions of $P$. gingivalis which required a sufficient amount of nutrient media. Further in oral cavity, a dilution effect by saliva and gingival crevicular flow has to be considered. Nevertheless, subsequent studies should test also higher concentrations of methylglyoxal.

In experiments using propolis, an inhibitory effect only in the concentration of $20 \mathrm{mg} / \mathrm{l}$ was found, the higher tested concentration of propolis did not have any effect on the counts of viable bacteria within biofilms. Probably the limited effect of propolis is not only due to the direct antimicrobial actions. Propolis negatively interacts with S. aureus adhesion and biofilm formation by inhibiting virulence factors in low concentration [43].

In addition to its antibacterial activity, immunmodulatory effects of honey have been described. Honey stimulates the release of inflammatory cytokines from monocytes [44], mRNA expression of TGF- $\beta$ as an wound-healing promoting cytokine is upregulated [45]. Propolis does not 
have a high cytotoxicity against periodontal ligament cells [46]. It suppresses syntheses of inflammatory cytokines, whereas TGF- $\beta 1$ is increased [47].

In an in vitro study it was shown that chlorhexidine acts more antibacterial than honey [48]. However, the addition of honey or its components as natural products to mouth rinses, tooth pastes may be discussed as a beneficial option in prevention and therapy of periodontitis. A subgingival irrigation with propolis extraxt improved the clinical parameters and reduced the counts of $P$. gingivalis [22]. In a pilot study including gingivitis patients, the usage of a chewing gum containing Manuka honey reduced the inflammatory variables and the plaque-score in comparison to a chewing gum without honey [19].

\section{Conclusions}

In conclusion, honey especially Manuka honey acts growthinhibitory on $P$. gingivalis as a major periodontopathogen. This effect on planktonic bacteria but not within biofilm is based on the ingredient methylglyoxal. Honey may destroy biofilms containing $P$. gingivalis. Therefore an addition of honey or its compounds to oral health-care products may have potential in prevention and treatment of periodontitis. More studies are needed to verify specifically the effect of honey and its compounds on oral species associated with periodontitis.

\section{Competing interests}

The authors declare that they have no competing interests.

\section{Authors' contributions}

SE participated in planning and designing the study as well as in the data analysis. GS performed the microbiological laboratory work. JK participated in study design and data analysis. JA and TH performed analysis of the honeys. WP participated in planning and designing the study. All authors participated in drafting the manuscript; they have read and approved the final manuscript.

\section{Acknowledgement}

We are grateful to Claudia Ranke (University Hospital Jena) for excellent assistance in performing the in vitro assays. The authors would like to thank Wilfried Dölz and Martin Kramesberger for providing us the local beekeeper honey and the propolis. Juergen W. Einax' (University of Jena) helpful advices for determination of hydrogen peroxide content within the honeys are highly appreciated. We are indebted Richard Miron (University of Bern) for language corrections and Walter Bürgin (University of Bern) for statistical advice. This study was institutionally funded. No external funding was provided.

\section{Author details \\ ${ }^{1}$ Department of Periodontology, Laboratory of Oral Microbiology, Dental School, University of Bern, Freiburgstrasse 7, CH-3010 Bern, Switzerland. ${ }^{2}$ Medical University Laboratories, Institute of Medical Microbiology, University Hospital of Jena, Jena, Germany. ${ }^{3}$ Department of Rheumatology and Inflammation Research, Sahlgrenska Academy, University of Gothenburg, Gothenburg, Sweden. ${ }^{4}$ Institute of Food Chemistry, Technische Universität Dresden, Dresden, Germany.}

Received: 17 December 2013 Accepted: 11 March 2014 Published: 25 March 2014

\section{References}

1. Ezzo PJ, Cutler CW: Microorganisms as risk indicators for periodontal disease. Periodontol 2000 2003, 32:24-35.
2. Genco RJ: Current view of risk factors for periodontal diseases. J Periodontol 1996, 67(10 Suppl):1041-1049.

3. Lamont RJ, Jenkinson HF: Subgingival colonization by Porphyromonas gingivalis. Oral Microbiol Immunol 2000, 15(6):341-349.

4. Hajishengallis G, Darveau RP, Curtis MA: The keystone-pathogen hypothesis. Nat Rev Microbiol 2012, 10(10):717-725.

5. Imamura $\mathrm{T}$ : The role of gingipains in the pathogenesis of periodontal disease. J Periodontol 2003, 74(1):111-118.

6. Santos S, Herrera D, Lopez E, O'Connor A, Gonzalez I, Sanz M: A randomized clinical trial on the short-term clinical and microbiological effects of the adjunctive use of a $0.05 \%$ chlorhexidine mouth rinse for patients in supportive periodontal care. J Clin Periodontol 2004, 31(1):45-51.

7. Cosyn J, Sabzevar MM: Subgingival chlorhexidine varnish administration as an adjunct to same-day full-mouth root planing. II. Microbiological observations. J Periodontol 2007, 78(3):438-445.

8. van Winkelhoff AJ, Winkel EG: Antibiotics in periodontics: right or wrong? J Periodontol 2009, 80(10):1555-1558.

9. Guentsch A, Jentsch H, Pfister W, Hoffmann T, Eick S: Moxifloxacin as an adjunctive antibiotic in the treatment of severe chronic periodontitis. J Periodontol 2008, 79(10):1894-1903.

10. Allaker RP, Douglas CW: Novel anti-microbial therapies for dental plaque-related diseases. Int J Antimicrob Agents 2009, 33(1):8-13.

11. Moon SE, Kim HY, Cha JD: Synergistic effect between clove oil and its major compounds and antibiotics against oral bacteria. Arch Oral Biol 2011, 56(9):907-916.

12. Cooper R: Honey in wound care: antibacterial properties. GMS Krankenhhyg Interdiszip 2007, 2(2):Doc51.

13. White JW Jr, Subers MH, Schepartz Al: The identification of inhibine, the antibacterial factor in honey, as hydrogen peroxide and its origin in a honey glucose-oxidase system. Biochim Biophys Acta 1963, 73:57-70.

14. Mavric E, Wittmann S, Barth G, Henle T: Identification and quantification of methylglyoxal as the dominant antibacterial constituent of Manuka (Leptospermum scoparium) honeys from New Zealand. Mol Nutr Food Res 2008, 52(4):483-489.

15. Al-Waili NS: Topical honey application vs. acyclovir for the treatment of recurrent herpes simplex lesions. Med Sci Monit 2004, 10(8):MT94-MT98.

16. Baghel PS, Shukla S, Mathur RK, Randa R: A comparative study to evaluate the effect of honey dressing and silver sulfadiazene dressing on wound healing in burn patients. Indian J Plast Surg 2009, 42(2):176-181.

17. Al-Waili NS, Saloom KY: Effects of topical honey on post-operative wound infections due to gram positive and gram negative bacteria following caesarean sections and hysterectomies. Eur J Med Res 1999, 4(3):126-130.

18. Sela M, Maroz D, Gedalia I: Streptococcus mutans in saliva of normal subjects and neck and head irradiated cancer subjects after consumption of honey. J Oral Rehabil 2000, 27(3):269-270.

19. English HK, Pack AR, Molan PC: The effects of manuka honey on plaque and gingivitis: a pilot study. J Int Acad Periodontol 2004, 6(2):63-67.

20. Viuda-Martos M, Ruiz-Navajas Y, Fernandez-Lopez J, Perez-Alvarez JA: Functional properties of honey, propolis, and royal jelly. J Food Sci 2008 73(9):R117-R124

21. Botushanov PI, Grigorov Gl, Aleksandrov GA: A clinical study of a silicate toothpaste with extract from propolis. Folia Med (Plovdiv) 2001, 43(1-2):28-30

22. Gebaraa EC, Pustiglioni AN, de Lima LA, Mayer MP: Propolis extract as an adjuvant to periodontal treatment. Oral Health Prev Dent 2003, 1(1):29-35.

23. Reichert JS, McNeight SA, Rudel HW: Determination of hydrogen peroxide and some related peroxygen compounds. Ind Eng Chem 1939, 31:194-197.

24. CLSI: Methods for antimicrobial susceptibility testing of anaerobic bacteria; Approved Standard-Seventh edition. In Volume 27. Wayne, PA, USA: Clinical and Laboratory Standards Institute Vol. 27 No. 2; 2007:M11-A17.

25. Basson NJ, Grobler SR: Antimicrobial activity of two South African honeys produced from indigenous Leucospermum cordifolium and Erica species on selected micro-organisms. BMC Complement Altern Med 2008, 8:41.

26. Lin SM, Molan PC, Cursons RT: The controlled in vitro susceptibility of gastrointestinal pathogens to the antibacterial effect of manuka honey. Eur J Clin Microbiol Infect Dis 2011, 30(4):569-574.

27. Lusby PE, Coombes AL, Wilkinson JM: Bactericidal activity of different honeys against pathogenic bacteria. Arch Med Res 2005, 36(5):464-467.

28. Badet C, Quero F: The in vitro effect of manuka honeys on growth and adherence of oral bacteria. Anaerobe 2011, 17:19-22.

29. Jervis-Bardy J, Foreman A, Bray S, Tan L, Wormald PJ: Methylglyoxal-infused honey mimics the anti-Staphylococcus aureus biofilm activity of manuka 
honey: potential implication in chronic rhinosinusitis. Laryngoscope 2011, 121(5):1104-1107.

30. Kwakman PH, te Velde AA, de Boer L, Vandenbroucke-Grauls CM, Zaat SA: Two major medicinal honeys have different mechanisms of bactericidal activity. PLoS One 2011, 6(3):e17709.

31. Koo H, Gomes BP, Rosalen PL, Ambrosano GM, Park YK, Cury JA: In vitro antimicrobial activity of propolis and Arnica montana against oral pathogens. Arch Oral Biol 2000, 45(2):141-148.

32. Koru O, Toksoy F, Acikel CH, Tunca YM, Baysallar M, Uskudar Guclu A, Akca E, Ozkok Tuylu A, Sorkun K, Tanyuksel M, Salih B: In vitro antimicrobial activity of propolis samples from different geographical origins against certain oral pathogens. Anaerobe 2007, 13(3-4):140-145.

33. Santos FA, Bastos EM, Rodrigues PH, de Uzeda M, de Carvalho MA, Farias Lde M, Moreira ES: Susceptibility of Prevotella intermedia/Prevotella nigrescens (and Porphyromonas gingivalis) to propolis (bee glue) and other antimicrobial agents. Anaerobe 2002, 8(1):9-15.

34. Eick S, Seltmann T, Pfister W: Efficacy of antibiotics to strains of periodontopathogenic bacteria within a single species biofilm - an in vitro study. J Clin Periodontol 2004, 31(5):376-383.

35. Kuboniwa M, Lamont RJ: Subgingival biofilm formation. Periodontol 2000 2010, 52(1):38-52.

36. Zijnge $\mathrm{V}$, van Leeuwen MB, Degener JE, Abbas F, Thurnheer T, Gmur R, Harmsen HJ: Oral biofilm architecture on natural teeth. PLoS One 2010, 5(2):e9321.

37. Keijser BJ, Zaura E, Huse SM, van der Vossen JM, Schuren FH, Montijn RC, ten Cate JM, Crielaard W: Pyrosequencing analysis of the oral microflora of healthy adults. J Dent Res 2008, 87(11):1016-1020

38. Jakubovics NS: Talk of the town: interspecies communication in oral biofilms. Mol Oral Microbiol 2010, 25(1):4-14.

39. van Winkelhoff AJ, Appelmelk BJ, Kippuw N, de Graaff J: K-antigens in Porphyromonas gingivalis are associated with virulence. Oral Microbio Immunol 1993, 8(5):259-265.

40. Chen T, Hosogi Y, Nishikawa K, Abbey K, Fleischmann RD, Walling J, Duncan $\mathrm{MJ}$ : Comparative whole-genome analysis of virulent and avirulent strains of Porphyromonas gingivalis. J Bacteriol 2004, 186(16):5473-5479.

41. Alandejani T, Marsan J, Ferris W, Slinger R, Chan F: Effectiveness of honey on Staphylococcus aureus and Pseudomonas aeruginosa biofilms. Otolaryngol Head Neck Surg 2009, 141(1):114-118.

42. Merckoll P, Jonassen TO, Vad ME, Jeansson SL, Melby KK: Bacteria, biofilm and honey: a study of the effects of honey on 'planktonic' and biofilm-embedded chronic wound bacteria. Scand J Infect Dis 2009, 41(5):341-347.

43. Scazzocchio F, D'Auria FD, Alessandrini D, Pantanella F: Multifactorial aspects of antimicrobial activity of propolis. Microbiol Res 2006, 161(4):327-333.

44. Tonks AJ, Cooper RA, Jones KP, Blair S, Parton J, Tonks A: Honey stimulates inflammatory cytokine production from monocytes. Cytokine 2003, 21(5):242-247.

45. Majtan J, Kumar P, Majtan T, Walls AF, Klaudiny J: Effect of honey and its major royal jelly protein 1 on cytokine and MMP-9 mRNA transcripts in human keratinocytes. Exp Dermatol 2010, 19:e73-79.

46. Al-Shaher A, Wallace J, Agarwal S, Bretz W, Baugh D: Effect of propolis on human fibroblasts from the pulp and periodontal ligament. $J$ Endod 2004, 30(5):359-361.

47. Ansorge $S$, Reinhold D, Lendeckel U: Propolis and some of its constituents down-regulate DNA synthesis and inflammatory cytokine production but induce TGF-beta1 production of human immune cells. $Z$ Naturforsch $C$ 2003, 58(7-8):580-589.

48. Aparna S, Srirangarajan S, Malgi V, Setlur KP, Shashidhar R, Setty S, Thakur S: A comparative evaluation of the antibacterial efficacy of honey in vitro and antiplaque efficacy in a 4-day plaque regrowth model in vivo: preliminary results. J Periodontol 2012, 83(9):1116-1121.

doi:10.1186/1472-6831-14-24

Cite this article as: Eick et al:: Honey - a potential agent against

Porphyromonas gingivalis: an in vitro study. BMC Oral Health 2014 14:24.

\section{Submit your next manuscript to BioMed Central and take full advantage of:}

- Convenient online submission

- Thorough peer review

- No space constraints or color figure charges

- Immediate publication on acceptance

- Inclusion in PubMed, CAS, Scopus and Google Scholar

- Research which is freely available for redistribution 